\title{
Review
}

\section{Universal anti-influenza vaccines based on viral HA2 and M2e antigens}

\author{
F. KOSTOLANSKÝ, K. TOMČÍKOVÁ, K. BRIESTENSKÁ, M. MIKUŠOVÁ, E. VAREČKOVÁ*
}

\begin{abstract}
Institute of Virology, Biomedical Research Center of the Slovak Academy of Sciences, Dúbravská cesta 9, 84505 Bratislava, Slovak Republic
\end{abstract}

Received July 8, 2020; accepted October 26, 2020

\begin{abstract}
Summary.-Aquatic birds are the main reservoir of influenza A viruses (IAVs). These viruses can infect humans repeatedly and cause acute respiratory disease with potential of spread in the form of epidemics. In addition, avian influenza viruses that overcome the interspecies barrier and adapt to humans can cause a world-wide pandemic with severe consequences to human health. Therefore, scientists are focused on the development of a "universal" vaccine with a broad protective efficacy, i.e. against different subtypes of influenza A viruses and not only against the currently co-circulating human epidemic strains. Nowadays, several new vaccine design strategies have been described. Most of them utilize the conserved stem part of influenza surface glycoprotein hemagglutinin (HA) or the ectodomain of M2 (M2e) protein with proton-channel activity. A comparison of the efficacy of novel vaccines and their protective mechanisms against influenza infection is discussed in this review and should be considered for the construction of the most effective broadly protective vaccine with minimal side effects. This is the essential goal in influenza virus research today, especially when the infection with new human coronavirus SARS-CoV-2 can interfere with the course of influenza virus infection.
\end{abstract}

Keywords: influenza A virus; HA2 gp; M2 ectodomain; universal vaccine

\section{Introduction}

Influenza A viruses (IAVs) cause the acute respiratory disease in humans. Influenza epidemics are repeated yearly due to the high IAV variability. Sometimes a new IAV emerges in human population and spreads rapidly among humans causing pandemics because of the lack

"Corresponding author. E-mail: viruevar@savba.sk; phone: +421-2-59302427.

Abbreviations: $A D C C$ = antibody-dependent cellular cytotoxicity; ADP = antibody-dependent phagocytosis; $\mathrm{HA}=$ hemagglutinin; HA1 = heavy chain of HA; HA2 = light chain of $\mathrm{HA} ; \mathrm{IAV}(\mathrm{s})=$ influenza A virus(es); IgG = immunoglobulin G; $\mathrm{KLH}=$ Keyhole limpet hemocyanin; $\mathrm{MAb}(\mathrm{s})=$ monoclonal antibody(ies); M2 = matrix protein 2; M2e = ectodomain of M2; $\mathrm{VLP}=$ virus-like particle of herd immunity. The main reservoir of zoonotic IAVs is waterfowl. Avian influenza viruses can overcome interspecies barrier and, after accumulation of adaptive mutations required for virus propagation, they can be transmitted to new host. Avian IAV can be adapted to humans or to other mammals (Herfst et al., 2014; Schrauwen and Fouchier, 2014; Saunders-Hastings and Krewski, 2016). The study of the amino acid markers specific for particular virus host is essential for the knowledge of possibilities and restrictions of inter-species transmission of zoonotic influenza viruses. Adaptive mutations leading to fixation of new host-specific markers were reported for human or equine IAVs (Miotto et al., 2010; Mucha et al., 2018).

Influenza infection of humans can have a spectrum of clinical symptoms from mild to severe, depending on the virus dose, the virulence of virus and the host immune 
system. During the usual epidemic season, characteristic manifestations of a relatively mild course of influenza infection include fever, myalgia, cough, weakness, but without health consequences. A severe course of illness appears especially in risk groups of patients - elderly people, immunocompromised persons, and patients suffering from chronic illness as are cardiovascular, respiratory (asthma), oncological diseases or metabolic disorders. In these cases, influenza infection may result in the viral pneumonia, sometimes even with fatal outcomes. Primary influenza infection is often associated with secondary bacterial respiratory infection that can have a dangerous progress (McCullers, 2014). Influenza can be treated with antivirotics - neuraminidase inhibitors, e.g. oseltamivir and zanamivir, or virus polymerase inhibitors, e.g. baloxavir and favipiravir (latter licensed in Japan only). However, all of the antivirotics mentioned above are effective when applied in the early phase of influenza infection (24-48 $\mathrm{h}$ after infection) and a later application would not be effective.

However, the most effective defense against influenza is the vaccination (Paules and Subbarao, 2017). Currently, two types of influenza vaccines containing IAV of $\mathrm{H} 1$ and H3 subtypes and one or two influenza B virus antigens are approved in human medicine. These are live attenuated vaccines, permitted only in USA and Russia, or inactivated vaccines (Nachbagauer et al., 2018; Sunwoo et al., 2018). The most commonly used inactivated vaccines are split virus vaccines and subunit vaccines containing purified surface glycoproteins of virus (Stropkovská et al., 2010; Soema et al., 2015). These influenza vaccines generally induce antibody response against the main immunogens of IAV, the surface glycoproteins hemagglutinin (HA) and neuraminidase (NA). Virus-neutralizing antibodies are targeted particularly against the globular part of HA, representing the highly variable region of HA. Because of the high variability of both, HA and NA, IAV can avoid the pre-existing immunity in human population and the effectivity of disease protection mediated by vaccination is lower (Gamblin and Skehel, 2010; van de Sandt et al., 2012). Therefore, it is necessary to evaluate seasonal vaccine effectiveness yearly and to re-design vaccine composition for the subsequent season. Effectiveness of seasonal anti-influenza vaccines ranges usually between $30 \%-70 \%$ (Kissling et al., 2014; Flannery et al., 2017). Another disadvantage is that currently used seasonal inactivated vaccines do not induce efficient cellular immune responses and mucosal immunity (Chen et al., 2001; Calzas and Chevalier, 2019; Mohn et al., 2020).

To avoid the necessity of seasonal changes in vaccine production and to provide the protection against various IAV subtypes, an effort is focused on the development of IAV vaccines based on immune recognition of anti- genically conserved IAV antigens (Gerhard et al., 2006; Brandenburg et al., 2013; Krammer, 2015; Krammer and Palese, 2015).

Such broadly cross-protective vaccines are targeted against the conserved parts of the surface IAV antigens HA, NA or matrix protein 2 (M2), eliciting mainly the antibody response (Gomez Lorenzo and Fenton, 2013). Another group of vaccines is targeted against internal proteins, matrix protein $1(\mathrm{M} 1)$ or nucleoprotein (NP), inducing the cross-protection mediated by antigen-specific T-cells (Sridhar et al., 2013; Epstein, 2018). In order to stimulate both virus-specific T-cell immunity and protective antibody response, some vaccines contain combination of internal proteins (NP, M1) with HA2 domain or M2 ectodomain (M2e), utilizing different ways of antigen presentation (Heinen et al., 2002; Stepanova et al., 2018; Tsybalova et al., 2018; Sun et al., 2019).

The majority of studies are focused on the HA2 and M2e, which are highly conserved even among different IAV subtypes. Though they are present on the surface of viral particle, their restricted accessibility is responsible for the low immunogenicity of these conserved antigens. Thus, the essential goal during the development of HA2or M2e-based vaccines is to achieve the most effective increase of their immunogenicity (Kwong and Wilson, 2009) and many strategies were developed to enhance HA2 and M2e presentation to the immune system.

\section{Strategies of the development of new HA2-based anti-influenza vaccines}

HA is the main surface antigen of IAV. It is a glycoprotein composed of three identical monomers connected by intermolecular bonds. Each monomer consists of two subunits, HA1 and HA2 glycopolypeptides linked by disulphide bonds, which are products of post-translational proteolytic cleavage of HA precursor (HAO) (Skehel and Wiley, 2000; Sriwilaijaroen and Suzuki, 2012). HA has a dual role during the virus entry into the cell: i) the virus attachment to the cell via receptor binding site on HAl globular part of HA trimer and ii) HA2 gp-mediated fusion of viral and endosomal membranes after internalization of virus into the endosome. The globular part of HA is immunodominant and induces virus-neutralizing antibodies that block the virus attachment to the cell surface by targeting the area near the HA receptor binding site. The stem of HA trimer is formed mainly by HA2 gp and only by small region of HAl. It is covered by globular part of HA, therefore, it is immunosubdominant (Fig.1). The high genetic and structural plasticity of globular HA domain allows its high antigenic variability under the selection pressure of virus-neutralizing antibodies present in hu- 

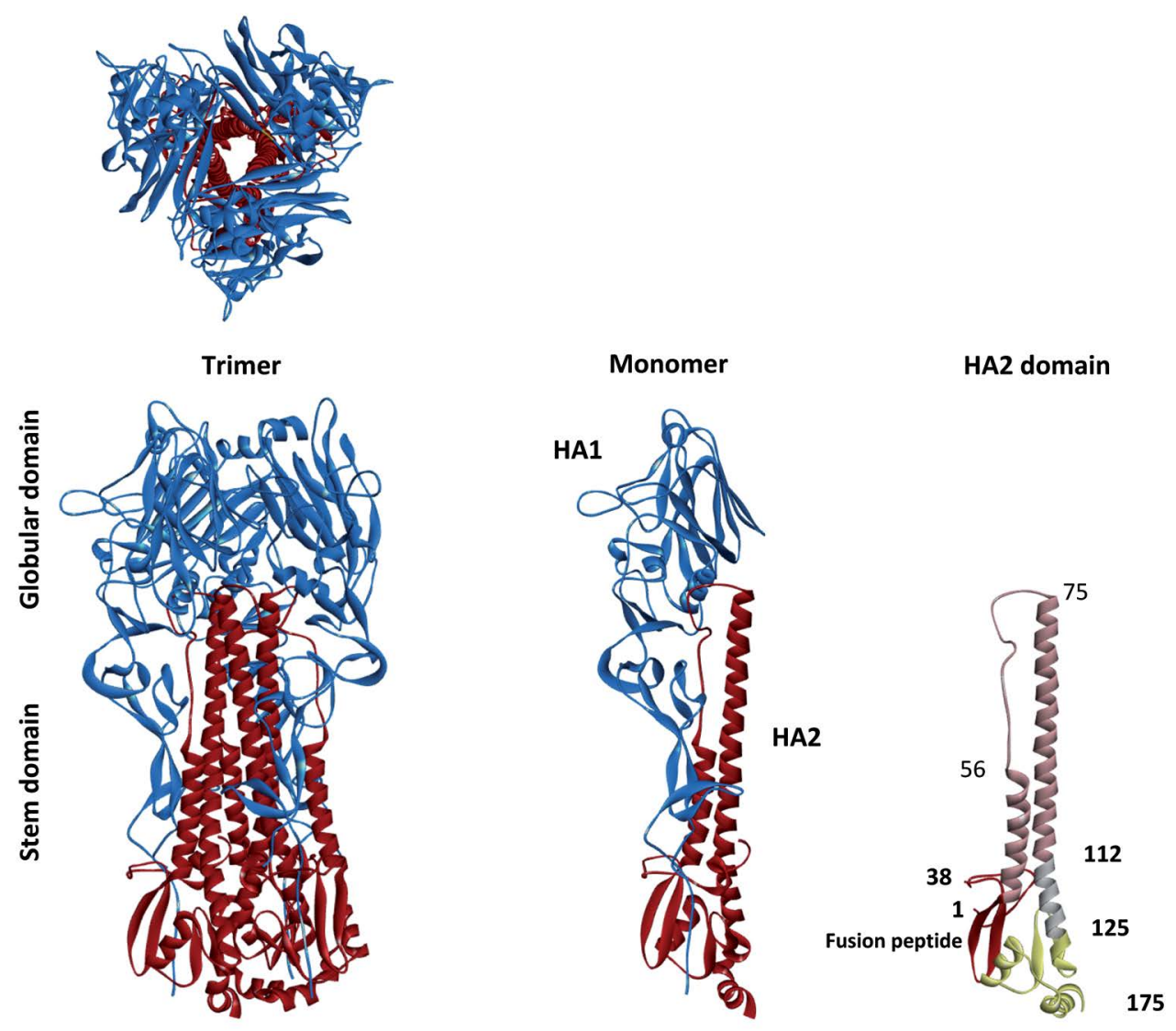

Fig. 1

The structure of hemagglutinin trimer, monomer and HA2 domain of influenza A H3 subtype

In the trimer and monomer molecule of HA, the immunodominant globular domain and immunosubdominant stem domain are colored blue and red, respectively. Despite the less accessible position of HA2 in the HA molecule, four antigenic regions were determined on HA2. Antigenic site I: red (aal-38), two different antigenic sites II and IV in the same region: yellow (aa125-175) and site III: pink (aa38-112). The figure was created in Discovery Studio 4.1 visualizer. Source: PDB 4WE4.

mans who have overcome the infection or were vaccinated (Isin et al., 2002; Vaccaro et al., 2005). However, HA2 gp is a relatively conserved part due to its localization inside the HA trimer. The conservation of HA2 gp structure is essential for preservation of the function of the HA trimer in the fusion process (Godley et al., 1992; Steinhauer, 1999; Cross et al., 2009; Langley et al., 2009; Hamilton et al., 2012). HA2 gp attracted attention of researchers as a potential immunogen for the cross-protective vaccine preparation because of its position in HA molecule, sequence similarity between HA of different IAV strains and structural stability required for the fusion process.

The important property of anti-HA2 antibodies as a high cross-reactivity of HA2-specific monoclonal or polyclonal antibodies documented in many studies predetermined HA2 gp to be suitable immunogen inducing cross-protection (for review see Graves et al., 1983; Becht et al.,1984; Sanchez-Fauquier et al., 1991; Okuno et al.,1993; Varečková et al.,2002,2008; Ekiert et al., 2009; Stropkovská et al., 2009; Ekiert et al., 2011; Tomčíková and Varečková, 2019).

Four antigenic sites on HA2 gp and their immunogenicity were described in our laboratory. It was shown that antibodies recognizing three of four antigenic sites inhibited the fusion activity of HA as well as the replication of different IAV subtypes and had protective potential in vivo (Varečková et al., 2003a,b; Gocník et al., 2007; Stropkovská et al., 2009). These antigenic sites (Fig. 1) were defined using anti-HA2 monoclonal antibodies. Site I was localized at aa position 1-38 of the N-terminus of HA2, site II and IV were localized in the region of aa125-175 of HA2. Monoclonal antibodies against these sites inhibited the fusion activity of $\mathrm{HA}$ and protected mice against the lethal influenza infection. Antigenic site III was localized in the aa region 38-112 of HA2, but antibody targeted against this site (MAb CB8) did not inhibit fusion activity of HA and did not protect mice against the infection (Varečková et al., 2003a,b, 2013; Gocník et al., 2007). However, another 
study revealed that repeated subclinical infection of mice with IAV results in the increased induction of HA2specific antibodies (Kostolanský et al., 2002). The levels of HA2-specific antibodies in convalescent human sera with confirmed influenza infection showed a raising trend with increasing age of patients (Staneková et al., 2012). These studies also demonstrated differences in the immunogenicity of particular antigenic sites on HA2 gp. The most immunogenic was the region aal25-175 of HA2 N-terminus (Staneková et al., 2012).

In parallel, other data about the ability of anti-HA2 antibodies to inhibit the virus replication or release have been published (Prabhu et al., 2009; Krammer and Palese, 2013, 2015; Margine et al., 2013a; Krammer, 2015; Nachbagauer et al., 2016; Nachbagauer and Palese, 2018; Košík et al., 2019), some of them were focused on the antibodies specific to the conformational epitope localized in the HA stem comprising HA1 and HA2 gps (Sui et al., 2009).

The researchers put a great effort into solving the problem of low accessibility and low immunogenicity of HA2 gp with the goal to induce broadly specific protective anti-HA2 antibodies (Angeletti et al., 2017). Various new strategies based on the more effective delivery or exposition of antigen to the immune system were developed (Staneková and Varečková, 2010; Wang et al., 2010; Krammer and Palese, 2013; Margine et al., 2013b; for review: Tomčíková and Varečková, 2019).

The first attempts to enhance the immunogenicity of HA2 gp utilized the carriers of different origins. As carries were frequently used Keyhole limpet hemocyanin (KLH) (Wang et al., 2010; Staneková et al., 2011; Janulíková et al., 2012; Nachbagauer et al., 2017), flagellin from the Salmonella typhimurium vaccine strain (Arnon, 2006; Ben-Yedida and Arnon, 2007; Stepanova et al., 2018), nanoparticles (Kanekiyo et al., 2013; Yassine et al., 2015), or virus-like particles (VLP) (Kang et al., 2012; Chen et al., 2015). These vectors enable to present antigen in many copies, resulting in increased robustness of specific immune response. Other approach utilized non-infectious Escherichia coli-derived plasmids as DNA vaccines (Katz et al.,2006). DNA vaccines induce $\mathrm{T}$ and B-cell immunity, similarly to virus vectors such as vaccinia virus (Gocník et al., 2008), hepatitis Bvirus or adenovirus (Nachbagauer and Krammer, 2017). Genetically detoxified bacterial adenylate cyclase toxin produced by gram-negative bacteria Bordetella pertussis (Staneková et al., 2013) has also been successfully used as a non-replicating vector presenting ectodomain of HA2 gp (aa23-185 of N-terminus HA2). It turned out to be a good inductor of cross-protective antibody and T-cell immune response against lethal influenza infection because of the way of antigen presentation using this vector.

At the same time, many experiments redirecting the immune response to the conserved part of HA by modulation of the immunization protocols were described (Hai et al., 2012; Krammer and Palese, 2014; Nachbagauer et al., 2018; Sunwoo et al., 2018). Multiple immunizations with chimeric molecules composed of the stem of one HA subtype and a globular part of different subtypes redirected the antibody response to the repeatedly presented conserved HA2-stem. These antibodies conferred anti-influenza protective immunity of broader efficacy (Margine et al. 2013a,b; Nachbagauer et al., 2014; Klausberger et al., 2016; Choi et al., 2019). Vaccination strategy with chimeric HA is based on the immune memory, when the repeated immunization attracts the immune response to the conserved HA2 domain. Strategy utilizing the HA lacking the globular part of HA trimer was reported by many authors (Sagawa et al., 1996; Bommakanti et al., 2010; Steel et al., 2010; Bommakanti et al., 2012). It was also shown that the changes in the number of glycosylation sites on HAl gp can refocus the immune response to the conserved HA2 gp (Vigerust et al., 2007; Medina et al., 2013; Eggink et al., 2014; Tate et al., 2014; Zhang et al., 2015).

A new approach for preparation of vaccine antigen by the reverse genetic method (Fodor et al., 1999; Neumann et al., 1999; Hoffmann et al., 2000; Kawaoka and Neumann, 2012) enabled the construction of attenuated or chimeric viruses that can consequently redirect the immune response to conserved immunosubdominant parts of viruses, such as the HA2 gp, M2e, or internal subdominant antigens (NP or M1 proteins), and simultaneously can stimulate the humoral as well as T-cell immune response (Klausberger et al., 2016). In addition to the utilization of HA2 gp as an immunogen with cross-protective potential, the significant progress has been documented in studies focused on the M2e protein as an inductor of broadlyprotective immunity.

\section{Strategies of the development of M2e-based anti-influenza vaccines}

M2 protein is 97 amino acid product of the second open reading frame of the IAV genome segment 7 . A relatively small number of M2 proteins (approx. 23-60) are present in the viral envelope. However, M2 protein is abundantly expressed in the plasma membrane of IAV-infected cells - its C-terminal part is located in the cytoplasmic space, while N-terminus (23 aa-long ectodomain) is localized extracellularly (Fig. 2). Whole M2 molecule, including ectodomain, is highly conserved. The M2 protein is critical to the IAV life cycle since it forms a homotetramer that acts as a proton-selective transmembrane channel (Pinto et al., 1992). The $\mathrm{M} 2$ channel allows $\mathrm{pH}$ regulation - acidification of the virion interior in endosome that triggers conformational changes in HA molecule leading to the fu- 




Fig. 2

Schematic illustration of matrix protein 2

M2 forms a proton-selective ion channel in viral or infected cell membranes. M2 assembles into tetramer and can be divided into three parts: extracellular domain, transmembrane domain, C-terminal (cytoplasmic) domain. Figure adapted according to Saelens (2019). (Source: PDB 210j; amino acid sequence (aa2-18) is derived from IAV A/Udorn/1972 H3N2, UniProtKB- Q20MD5).

sion of the viral and the endosomal membranes (Wharton et al., 1994; Leiding et al., 2010; Mezhenskaya et al., 2019).

Vaccines based on the conserved sequence of M2 protein ectodomain (M2e) induce specific response that limits the replication and spread of the virus in the respiratory tract. This fact was first implied in a study showing that passive administration of M2-specific MAb $14 \mathrm{C} 2$ to mice was able to restrict virus multiplication and accelerate lung viral clearance following a sublethal IAV challenge. Moreover, localisation of virus protein M2 in the virion as well as in infected cells was unveiled by $14 \mathrm{C} 2$ (Zebedee and Lamb, 1988, 1989; Treanor et al., 1990).

M2e contains several well-documented overlapping B-cell epitopes, MHC-I or MHC-II restricted epitopes, and also epitopes for some HLA molecules. The most important are B-cell epitopes and epitopes with MHC-II restriction for CD4+ T-cellular response (Mozdzanowska et al., 2003; Zhang et al., 2006; Grandea III et al., 2010; Grant et al., 2014; Eliasson et al., 2017).

Anti-M2e antibodies do not neutralize the virus directly, but they have the ability to suppress the virus replica- tion via involvement of antibody Fc-fragment into the immune response. M2e-specific antibodies act against IAV by the mechanism of antibody-dependent cellular cytotoxicity (ADCC) or antibody-dependent phagocytosis (ADP), resulting in the elimination of infected cells (Jegerlehner et al., 2004; El Bakkouri et al., 2011). Targeting vaccines to M2e makes it possible to achieve specific and long-term immune response mediated not only by antibodies, but also by effector and memory CD4+ T-cells (Staneková and Varečková, 2010; Schotsaert et al., 2013; Eliasson et al., 2017; Jageskanda et al., 2017; Kolpe et al., 2017).

The major challenge in the development of effective antiviral M2e-based vaccine is to overcome the weak immunogenicity of this molecule (Zhong et al., 2014). Similarly as for the HA2-based vaccines, various approaches were used to enhance immunogenicity of M2e.

For more effective presentation of M2e to the immune cells and higher activation of humoral and T-cell immunity, viral vectors based on baculoviruses (Black et al., 1993; Slepushkin et al.,1995), papaya mosaic virus (PapMV) (Denis et al.,2008), vaccinia viruses (Hessel et al.,2014) and 
adenoviruses (Coughlan et al., 2015) have been utilized as antigen carriers. Promising method for elicitation of a robust immune response is also DNA vaccination with plasmid DNA that comprises genetic information for M2e (Yao et al., 2019). Another option is represented by adjuvant substances applied together with the immunogen (Eliasson et al., 2008) or carriers such as KLH (Fan et al., 2004; De Filette et al., 2011), nanoparticles, or VLP (Tao et al., 2014, Kim et al., 2013; Wang et al., 2014; Deng et al, 2015).

Besides the way of immunogenicity improvement, an interesting question remains open: Which of the two influenza proteins - HA2 or M2e - provides more effective antiviral protection?

A simple comparison of in vivo immunization with KLH-conjugated HA2 fusion peptide 1-38 and M2e was performed (Staneková et al., 2011). Repeatedly immunized mice were challenged with the lethal dose of homologous A/Mississippi/1/85(H3N2) or heterologous $\mathrm{A} / \mathrm{PR} / 8 / 34(\mathrm{H} 1 \mathrm{~N} 1)$ influenza A viruses. Immunization with the fusion peptide led to a $100 \%$ survival of mice infected with $1 \mathrm{LD}_{50}$ of homologous as well as heterologous virus. However, survival rate decreased when the infectious dose was raised to $2 \mathrm{LD}_{50}$. The immunization with M2e induced effective cross-protection of mice infected even with $3 \mathrm{LD}_{50}$ of both challenge viruses. Even though the protection induced by the HA2 fusion peptide was lower, it was still effective. Results of this study suggested that apart from the ectodomain of M2, HA2 fusion peptide could also be considered as a part of cross-protective influenza vaccine (Staneková et al., 2011).

Another question of interest could be the quantification of the immunogen-specific antibodies necessary for protective effect against lethal dose of challenged mice. In passive transfer experiments, mice were immunized by intravenous route with different doses of anti-M2e polyclonal IgG in range from 40 to $320 \mu$ g and control mice were administered $320 \mu \mathrm{g}$ of anti-KLH IgGs. The survival of these mice subsequently infected with $3 \mathrm{LD}_{50}$ IAV was determined. An absolute protection (100\% survival) was obtained with $320 \mu$ g of anti-eM2 IgGs, and a relatively strong protection ( $~ 80 \%$ survival, $\mathrm{p}=0.024)$ with $160 \mu \mathrm{g}$. The amount $160 \mu \mathrm{g}$ of IgGs represents approx. $100 \mu \mathrm{g}$ IgGs per $1 \mathrm{ml}$ of blood (Király et al., 2011). These findings agree with the results obtained by Fu et al.(2009), who evaluated anti-M2e protective response, however, using of MAbs at doses of 0.2-2.0 mg per mouse. Another research group (Beerli et al., 2009) found that the most effective anti-M2e MAb provided satisfactory protection against infection with $4 \mathrm{LD}_{50}$ of virus even at dose of $20 \mu$ g per mouse. Such a high efficiency can be most probably ascribed to the high affinity $\left(\mathrm{K}_{\mathrm{d}}=4 \mathrm{nmol} / \mathrm{l}\right)$ of that particular MAb.

According to recently published experiments, there is a trend to use the combination of both M2e and HA2 im- munogens in a single recombinant vaccine. One group of authors combined M2e and HA2 (aa76-130) inserted into the full-length flagellin from Salmonella typhimurium (Flg). Such vaccine administered subcutaneously to mice greatly increased antigen-specific T-cell response and provided full protection from lethal challenge with $\mathrm{A} / \mathrm{H} 3 \mathrm{~N} 2$ and A/H7N9 (Stepanova et al., 2018). Alternatively, these authors inserted HA2 polypeptide (aa76-130) into the recombinant Flg4M2e protein. Intranasal immunization of BALB/c mice with this protein considerably induced mucosal and systemic responses directed against both proteins with resulting antiviral effect and complete protection from lethal challenge with influenza viruses A/H3N2, A/H2N2, and A/H5N1 (Tsybalova et al., 2018). Another research team developed an inactivated influenza virus with M2e epitope (aa2-16) inserted into the Ca2 antigenic site of A/PR8/34 (H1N1). Sequential immunization with these inactivated viruses substantially enhanced anti-M2e as well as anti-stalk region antibody responses providing superior protection of mice against a challenge with $5 \mathrm{LD}_{50}$ of X-31 (H1N1) virus (Sun et al., 2019).

\section{Conclusion}

Summarizing the situation in the research and development of new anti-influenza vaccines with broader efficacy, the conclusion can be made that a vaccine based on the combination of both HA2 and M2e proteins seems to be the most promising one. Current vaccines are targeted against the globular HAl part of influenza hemagglutinin and antibodies against this domain inhibit attachment and entry of virus into the infected cells. These vaccines thus neutralize the infectivity of virus. However, HAl gp is the most variable part of HA and antibodies are not always effective against new variants that usually cause the epidemic next season. Therefore, vaccines must be updated yearly. On the other hand, antibodies targeting conserved HA2 and M2e antigens do not neutralize virus. The HA2-specific antibodies mediate the protection against influenza infection in two ways: the direct effect of antibody that binds to the HA2 gp, resulting in the inhibition of the fusion process or blocking the HA conformational changes on endocytosed virus. As a consequence, the virus replication is restricted. Another way is the mechanism comprising the effector function of these antibodies (de Vries et al., 2017; Tomčíková and Varečková, 2019). Anti-M2e antibodies, however, mediate the protection by their effector function only (Jegerlehner et al., 2004; El Bakkouri et al., 2011). Recently published data suggest that the development of universal anti-influenza vaccine may be achieved by combination of suitable vaccine candidates, such as conserved epitopes from IAV 
proteins (HA, NP, M), and novel vaccination platforms (Nachbagauer and Palese, 2020; Vogel and Manicassamy, 2020). Further research is required to find an answer and for better understanding of these processes.

Acknowledgment. This work was supported by grants from Scientific Grant Agency of the Ministry of Education of the Slovak Republic and Slovak Academy of Sciences: 2/0048/19 (EV), 2/0106/17 (FK), and the Slovak Research and Development Agency grant APVV-17-0445 (EV).

\section{References}

Angeletti D, Gibbs JS, Angel M, Kosik I, Hickman HD, Frank GM, Das SR, Wheatley AK, Prabhakaran M, Leggat DJ, Mcdermott AB, Yewdell JW., Nat. Immunol.18,456-463, 2017. https://doi.org/10.1038/ni.3680

Arnon R., BTi 18, 10-13, 2006.

Beerli RR, Bauer M, Schmitz N, Buser RB, Gwerder M, Muntwiler S, Renner WA, Saudan P, Bachmann MF., Virol. J. 6(224), 11, 2009. https://doi.org/10.1186/1743-422X-6-224

Becht H, Huang RTC, Fleischer B, Boschek CB, Rott R., J. Gen. Virol. 65, 173-183, 1984. https://doi.org/10.1099/00221317-65-1-173

Ben-Yedida T, Arnon R., Expert. Rev. Vaccines 6, 939-948, 2007. https://doi.org/10.1586/14760584.6.6.939

Black RA, Rota PA, Gorodkova N, Klenk HD, Kendal AP., J Gen Virol. 74,143-146, 1993. https://doi.org/10.1099/00221317-74-1-143

Bommakanti G, Citron MP, Hepler RW, Callahan C, Heidecker GJ, Najar TA, Lu X, Joyce JG, Shiver JW, Casimiro DR, ter Meulen J, Liang X, Varadarajan R., Proc. Natl. Acad. Sci. USA 107(31),13701-13706, 2010.https://doi.org/10.1073/ pnas. 1007465107

Bommakanti G, Lu X, Citron MP, Najar TA, Heidecker GJ, ter Meulen J, Varadarajan R, Liang X., J. Virol. 86(24), 13434-13444, 2012. https://doi.org/10.1128/JVI.01429$\underline{12}$

Brandenburg B, Koudstaal W, Goudsmit J, Klaren V, Tang C, Bujny MV, Korse HJWM, Kwaks T, Otterstrom JJ, Juraszek J, van Oijen AM, Vogels R, Friesen RHE., PLoS One 8(12), e80034,2013. https://doi.org/10.1371/journal. pone.0080034

Calzas C, Chevalier C., Front. Immunol. 10, 1605, 2019. https:// doi.org/10.3389/fimmu.2019.01605

Chen D, Periwal SB, Larrivee K, Zuleger C, Erickson CA, Endres RL, Payne LG., J. Virol. 75(17), 7956-7965, 2001. https:// doi.org/10.1128/JVI.75.17.7956-7965.2001

Chen S, Zheng D, Li C, Zhang W, Xu W, Liu X, Fang F, Chen Z., Biomed. Res. Int. 2015, 901817, pp. 12, 2015. https://doi. org/10.1155/2015/901817

Choi A, Bouzya B, Cortés Franco KD, Stadlbauer D, Rajabhathor A, Rouxel RN, Mainil R, Van der Wielen M, Palese P, García-Sastre A, Innis BL, Krammer F, Schotsaert M, Mallett CP, Nachbagauer R., Immunohorizons 3(4),
133-148, 2019. https://doi.org/10.4049/immunohorizons.1900022

Coughlan L, Mullarkey C, Gilbert S., J Pharm Pharmacol. 67(3), 382-99, 2015. https://doi.org/10.1111/iphp.12350

Cross KJ, Langley WA, Russell RJ, Skehel JJ, Steinhauer DA., Protein Pept. Lett. 16, 766-778, 2009. https://doi. org/10.2174/092986609788681715

De Filette M, Ysenbaert T, Roose K, Schotsaert M, Roels S, Goossens E, Schepens B, Fiers W, Saelens X., J. Gen. Virol. 92(Pt 2), 301-306, 2011. https://doi.org/10.1099/ vir.0.027086-0

Deng L, Cho KJ, Fiers W, Saelens X., Vaccines 3(1), 105-136, 2015. https://doi.org/10.3390/vaccines3010105

Denis J, Acosta-Ramirez E, Zhao Y, Hamelin ME, Koukavica I, Baz M, Abed Y, Savard C, Pare C, Lopez Macias C, Boivin G, Leclerc D., Vaccine 26(27-28), 3395-3403, 2008. https:// doi.org/10.1016/j.vaccine.2008.04.052

deVries RD, Nieuwkoop NJ, Pronk MR, Bruin ED, Leroux-Roels GG, Huijskens EG, Binnendijk RS, Krammer F, Koopmans MP, Rimmelzwaan GF., Vaccine, 35(2), 238-247, 2017. https://doi.org/10.1016/j.vaccine.2016.11.082

Eggink D, Goff PH, Palese P., J. Virol. 88(1), 699-704, 2014. https:// doi.org/10.1128/JVI.02608-13

Ekiert DC, Bhabha G, Elsliger MA, Friesen RH, Jongeneelen M, Throsby M, Goudsmit J, Wilson IA., Science 324(5924), 246-251, 2009. https://doi.org/10.1126/science.1171491

Ekiert DC, Friesen RH, Bhabha G, Kwaks T, Jongeneelen M, Yu W, Ophorst C, Cox F, Korse HJ, Brandenburg B, Vogels R, Brakenhoff JP, Kompier R, Koldijk MH, Cornelissen LA, Poon LL, Peiris M, Koudstaal W, Wilson IA, Goudsmit J., Science 333(6044), 843-850,2011. https:// doi.org/10.1126/science.1204839

El Bakkouri K, Descamps F, De Filette M, Smet A, Festjens E, Birkett A, Van Rooijen N, Verbeek S, Fiers W, Saelens X., J. Immunol. 186(2), 1022-1031, 2011. https://doi. org/10.4049/jimmunol.0902147

Eliasson DG, El Bakkouri K, Schön K, Ramne A, Festjens E, Löwenadler B, Fiers W, Saelens X, Lycke N., Vaccine 26(9), 1243-1252, 2008. https://doi.org/10.1016/i.vaccine.2007.12.027

Eliasson DG, Omokanye A, Schon K, Wenzel UA, Bernasconi V, Bemark M, Kolpe A, El Bakkouri K, Ysenbaert T, Deng L, Fiers W, Saelens X, Lycke N., Mucosal. Immunol. 11(1), 273-289, 2017. https://doi.org/10.1038/mi.2017.14

Epstein SL., Am. J. Epidemiol. 187(12), 2603-2614, 2018. https:// doi.org/10.1093/aje/kwy145

Fan J, Liang X, Horton MS, Perry HC, Citron MP, Heidecker GJ, Fu TM, Joyce J, Przsysiecki CT, Keller PM, Garsky VM, Ionescu R, Rippeon Y, Shi L, Chastain MA, Condra JH, Davies ME, Liao J, Emini EA, Shiver JW., Vaccine 22(23-24), 2993-3003, 2004. https://doi.org/10.1016/i. vaccine.2004.02.021

Flannery B, Chung JR, Thaker SN, Monto AS, Martin ET, Belongia EA, McLean HQ, Gaglani M, Murthy K, Zimmerman RK, Nowalk MP, Jackson ML, Jackson LA, Foust A, Sessions W, Berman L, Spencer S, Fry AM., MMWR Morb. Mortal. Wkly. Rep. 66(6),167-171,2017. https://doi.org/10.15585/ mmwr.mm6606a3 
Fodor E, Devenish L, Engelhardt OG, Palese P, Brownlee GG, García-Sastre A., J. Virol. 73 (11), 9679-9682, 1999. https://doi.org/10.1128/JVI.73.11.9679-9682.1999

Fu TM, Freed DC, Horton MS, Fan J, Citron MP, Joyce JG, Garsky VM, Casimiro DR, Zhao Q, Shiver JW, Liang X., Virology 385, 218-226, 2009. https://doi.org/10.1016/j. virol.2008.11.035

Gamblin SJ, Skehel JJ., J. Biol. Chem. 285(37), 28403-28409, 2010. https://doi.org/10.1074/jbc.R110.129809

Gerhard W, Mozdzanowska K, Zharikova D., Emerg. Infect. Dis. 12(4), 569-574, 2006. https://doi.org/10.3201/ eid1204.051020

Gocník M, Fislová T, Mucha V, Sládková T, Russ G, Kostolanský F, Varečková E., J. Gen. Virol. 89, 958-967, 2008. https:// doi.org/10.1099/vir.0.83524-0

Gocník M, Fislová T, Sládková T, Mucha V, Kostolanský F, Varečková E., J. Gen. Virol. 88, 951-955, 2007. https:// doi.org/10.1099/vir.0.82563-0

Godley L, Pfeifer J, Steinhauer D, Ely B, Shaw G, Kaufmann R, Suchanek E, Pabo C, Skehel JJ, Wiley DC, Wharton S., Cell 68, 635-645, 1992. https://doi.org/10.1016/00928674(92)90140-8

Gomez Lorenzo MM, Fenton MJ., Chest 143(2), 502-510, 2013. https://doi.org/10.1378/chest.12-1711

Grandea III AG, Olsen OA, Cox TC, Renshaw M, Hammond PW, Chan-Hui P, Mitcham JL, Cieplak W, Stewart SM, Grantham ML, Pekosz A, Kiso M, Shinya K, Hatta M, Kawaoka Y, Moyle M., Proc. Natl. Acad. Sci. USA 107(28), 12658-12663, 2010. https://doi.org/10.1073/ pnas.0911806107

Grant EJ, Chen L, Quinones-Parra S, Pang K, Kedzierska K, Chen W., Crit. Rev. Immunol. 34(1), 15-39, 2014. https://doi. org/10.1615/CritRevImmunol.2013010019

Graves PN, Schulman JL, Young JF, Palese P., Virology 126, 106116,1983.https://doi.org/10.1016/0042-6822(83)90465-8

Hai R, Krammer F, Tan GS, Pica N, Eggink D, Maamary J, Margine I, Albrecht RA, Palese P., J. Virol. 86(10), 5774-5781, 2012. https://doi.org/10.1128/JVI.00137-12

Hamilton BS, Whittaker GR, Daniel S., Viruses 4, 1144-1168, 2012. https://doi.org/10.3390/v4071144

Heinen PP, Rijsewijk FA, de Boer-Luijtzev EA, Bianchi AT., J Gen Virol.83,1851-1859,2002. https://doi.org/10.1099/00221317-83-8-1851

Herfst S, Imai M, Kawaoka Y, Fouchier RAM., Curr Top Microbiol. Immunol. 385, 137-155, 2014. https://doi. org/10.1007/82 $2014 \quad 387$

Hessel A, Savidis-Dacho H, Coulibaly S, Portsmouth D, Kreil TR, Crowe BA, Schwendinger MG, Pilz A, Barrett PN, Falkner FG, Schäfer B., PLoS One 9(2), e88340, 2014. https://doi.org/10.1371/journal.pone.0088340

Hoffmann E, Neumann G, Kawaoka Y, Hobom G, Webster RG., Proc. Natl. Acad. Sci. USA 97(11), 6108-6113, 2000. https://doi.org/10.1073/pnas.100133697

Isin B, Doruker P, Bahar I., Biophys J. 82, 569-581, 2002. https:// doi.org/10.1016/S0006-3495(02)75422-2

Jageskanda S, Vanderven HA, Wheatley AK, Kent SJ., Hum Vaccin Immunother. 13(6), 1-9, 2017.
Janulíková J, Staneková Z, Mucha V, Kostolanský F, Varečková E., Acta Virol.56(3),169-176,2012.https://doi.org/10.4149/ av $201203 \quad 169$

Jegerlehner A, Schmitz N, Storni T, Bachmann MF., J. Immunol. 172(9), 5598-5605, 2004. https://doi.org/10.4049/jimmunol.172.9.5598

Kanekiyo M, Wei CJ, Yassine HM, Mctamney PM, Boyington JC, Whittle JRR, Rao SS, Kong WP, Wang L, Nabel GJ., Nature 499(7456), 102-106, 2013. https://doi.org/10.1038/ nature12202

Kang SM, Kim MC, Compans RW., Expert Rev Vaccines 11(8), 995-1007, 2012. https://doi.org/10.1586/erv.12.70

Katz JM, Garg S, Sambhara S., (2006): Influenza Vaccines: Current and Future Strategies. In Kawaoka Y: Influenza Virology: Current Topics. Caister Academic Press, U.K., pp. 203-228. ISBN: 978-1-904455-06-6

Kawaoka Y, Neumann G (2012): Influenza viruses: an introduction. In Influenza virus - Methods and Protocols. Methods Mol Biol. 2012, 865, 1-9. ISBN 978-1-61779-620-3. https://doi.org/10.1007/978-1-61779-621-0 1

Kim MC, Song JM, O E, Kwon YM, Lee YJ, Compans RW, Kang SM., Mol.Ther.21(2), 485-492,2013. https://doi.org/10.1038/ mt.2012.246

Király J, Varečková E, Mucha V, Kostolanský F., Acta Virol. 55(3), 261-265, 2011. https://doi.org/10.4149/av 201103261

Kissling E, Valenciano M, Buchholz U, Larrauri A, Cohen JM, Nunes B, Rogalska J, Pitigoi D, Paradowska-Stankiewicz I, Reuss A, Jiménez-Jorge S, Daviaud I, Guiomar R, O'Donell J, Necula G, Głuchowska M, Moren A., Euro. Surveill. 19(6), pii: 20701, 2014. https://doi. org/10.2807/1560-7917.ES2014.19.6.20701

Klausberger M, Tscheliessnig R, Neff S, Nachbagauer R, Wohlbold T, Wilde M, Palmberger D, Krammer F, Jungbauer A, Grabherr R., PLoS One 11(4), e0153579, 2016. https://doi.org/10.1371/journal.pone.0153579

Kolpe A, Schepens B, Fiers W, Saelens X., Expert Rev. Vaccines 16(2), 123-136, 2017. https://doi.org/10.1080/14760584. 2017.1240041

Kostolanský F, Mucha V, Slováková R, Varečková E., Acta Virol. 46(4), 229-236, 2002.

Košík I, Angeletti D, Gibbs JS, Angel M, Takeda K, Košíková M, Nair V, Hickman HD, Xie H, Brooke CB, Yewdell JW., J. Exp. Med.216(2),304-316,2019. https://doi.org/10.1084/ jem.20181624

Krammer F., Biotechnol J. 10(5), 690-701, 2015. https://doi. org/10.1002/biot.201400393

Krammer F, Palese P., Curr. Opin. Virol. 3(5), 521-530, 2013. https://doi.org/10.1016/j.coviro.2013.07.007

Krammer F, Palese P., Nat. Immunol. 15(1), 3-5, 2014. https://doi. org/10.1038/ni.2761

Krammer F, Palese P., Nat. Rev. Drug Discov. 14(3), 167-182, 2015. https://doi.org/10.1038/nrd4529

Kwong PD, Wilson IA., Nat. Immunol. 10(6), 573-578, 2009. https://doi.org/10.1038/ni.1746

Langley WA, Thoennes S, Bradley KC, Galloway SE, Talekar GR, Cummings SF, Varečková E, Russell RJ, Steinhauer DA. Virology 394(2),321-330,2009.https://doi.org/10.1016/j. virol.2009.08.031 
Leiding T, Wang J, Martinsson J, DeGrado WF, Arskold SP., Proc. Natl. Acad. Sci. USA 107(35), 15409-15414,2010. https:// doi.org/10.1073/pnas.1009997107

Margine I, Krammer F, Hai R, Heaton NS, Tan GS, Andrews SA, Runstadler JA, Wilson PC, Albrecht RA, García-Sastre A, Palese P., J. Virol. 87(19),10435-10446,2013a. https:// doi.org/10.1128/JVI.01715-13

Margine I, Hai R, Albrecht RA, Obermoser G, Harrod AC, Banchereau J, Palucka K, García-Sastre A, Palese P, Treanor JJ, Krammer F., J. Virol. 87(8), 4728-4737, 2013b. https://doi.org/10.1128/JVI.03509-12

McCullers JA., Nat. Rev. Microbiol.12, 252-262, 2014. https://doi. org $/ 10.1038 /$ nrmicro3231

Medina RA, Stertz S, Manicassamy B, Zimmermann P, Sun X, Albrecht RA, Uusi-Kerttula H, Zagordi O, Belshe RB, Frey SE, Tumpey TM, García-Sastre A., Sci. Transl. Med. 5(187), 187ra70, 2013. https://doi.org/10.1126/ scitranslmed.3005996

Mezhenskaya D, Isakova-Sivak I, Rudenko L., J Biomed Sci. 26(1), 76, pp. 15, 2019. https://doi.org/10.1186/s12929019-0572-3

Miotto O, Heiny AT, Albrecht R, García-Sastre A, Tan TW, August JT, Brusic V., PLoS One 5(2), e9025, 2010. https://doi. org/10.1371/journal.pone.0009025

Mohn KG, Brokstad KA, Islam S, Oftung F, Tøndel C, Aarstad HJ, Cox RJ., J Infect Dis. 221(9), 1528-1537, 2020. https://doi. org/10.1093/infdis/jiz583

Mozdzanowska K, Feng J, Eid M, Kragol G, Cudic M, Otvos L, Gerhard W., Vaccine 21(19-20), 2616-2626,2003. https:// doi.org/10.1016/S0264-410X(03)00040-9

Mucha V, Hollý J, Varečková E, Kostolanský F., Acta Virol. 62(3), 266-276, 2018. https://doi.org/10.4149/av_2018_220

Nachbagauer R, Choi A, Hirsh A, Margine I, Iida S, Barrera A, Ferres M, Albrecht RA, García-Sastre A, Bouvier NM, Ito K, Medina RA, Palese P, Krammer F., Nat. Immunol. 18(4), 464-473, 2017. https://doi.org/10.1038/ni.3684

Nachbagauer R, Krammer F., Clin. Microbiol. Infect. 23(4), 222-228,2017.https://doi.org/10.1016/j.cmi.2017.02.009

Nachbagauer R, Krammer F, Albrecht RA., Vaccines 6(3), 47, 11, 2018. https://doi.org/10.3390/vaccines6030047

Nachbagauer R, Miller MS, Hai R, Ryder AB, Rose JK, Palese P, García-Sastre A, Krammer F, Albrecht RA., J. Virol. 90(6), 3268-3273, 2016. https://doi.org/10.1128/ JVI.02481-15

Nachbagauer R, Palese P., Curr. Opin. Immunol. 53, 51-57, 2018. https://doi.org/10.1016/j.coi.2018.04.001

Nachbagauer R, Palese P., Annu. Rev. Med. 71, 315-327, 2020. https://doi.org/10.1146/annurev-med-120617-041310

Nachbagauer R, Wohlbold TJ, Hirsh A, Hai R, Sjursen H, Palese P, Cox RJ, Krammer F., J. Virol. 88(22), 13260-13268, 2014. https://doi.org/10.1128/JVI.02133-14

Neumann G, Watanabe T, Ito H, Watanebe S, Goto H, Gao P, Hughes M, Perez DR, Donis R, Hoffmann E, Hobom G, Kawaoka Y., Proc. Natl. Acad. Sci. USA 96(16), 9345-9350, 1999. https://doi.org/10.1073/pnas.96.16.9345

Okuno Y, Isegawa Y, Sasao F, Ueda S., J. Virol. 67(5), 2552-2558, 1993. https://doi.org/10.1128/JVI.67.5.2552-2558.1993
Paules C, Subbarao K., Lancet 390(10095), 697-708, 2017. https:// doi.org/10.1016/S0140-6736(17)30129-0

Pinto LH, Holsinger LJ, Lamb RA., Cell 69(3), 517-28, 1992. https:// doi.org/10.1016/0092-8674(92)90452-I

Prabhu N, Prabakaran M, Ho Hui-Ting, Velumani S, Qiang J, Goutama M, Kwang J., J. Virol. 83(6), 2553-2562, 2009. https://doi.org/10.1128/JVI.02165-08

Saelens X., J. Infect. Dis. 219 (Suppl.1), S68-S74, 2019. https://doi. org/10.1093/infdis/iiz003

Sagawa H, Ohshima A, Kato I, Okuno Y, Isegawa Y., J. Gen. Virol. 77(Pt 7), 1483-1487, 1996. https://doi.org/10.1099/00221317-77-7-1483

Sanchez-Fauquier A, Guillen M, Martin J, Kendal AP, Melero JA., Arch. Virol. 116(1-4), 285-293, 1991. https://doi. org/10.1007/BF01319250

Saunders-Hastings PR, Krewski D., Pathogens 5(4), 66, 19, 2016. https://doi.org/10.3390/pathogens5040066

Schotsaert M, Ysenbaert T, Neyt K, Ibanez LI, Bogaert P, Schepens B, Lambrecht BN, Fiers W, Saelens X., Mucosal. Immunol. 6(2), 276-287, 2013. https://doi.org/10.1038/ mi.2012.69

Schrauwen EJA, Fouchier RAM., Emerg. Microbes Infect. 3(2), e9, 2014. https://doi.org/10.1038/emi.2014.9

Skehel JJ, Wiley DC., Ann. Rev. Biochem. 69, 9868-9872, 2000. https://doi.org/10.1146/annurev.biochem.69.1.531

Slepushkin VA, Katz JM, Black RA, Gamble WC, Rota PA, Cox NJ., Vaccine 13(15), 1399-1402, 1995. https://doi. org/10.1016/0264-410X(95)92777-Y

Soema PC, Kompier R, Amorij JP, Kersten GF., Eur J Pharm Biopharm. 94, 251-263, 2015. https://doi.org/10.1016/i. ejpb.2015.05.023

Sridhar S, Begom S, Bermingham A, Hoschler K, Adamson W, Carman W, Bean T, Barclay W, Deeks JJ, Lalvani A., Nat. Med. 19(10), 1305-1312, 2013. https://doi.org/10.1038/ nm.3350

Sriwilaijaroen N, Suzuki Y., Proc. Jpn. Acad. Ser. B Phys. Biol. Sci. 88(6),226-249,2012.https://doi.org/10.2183/pjab.88.226

Staneková Z, Adkins I, Kosová M, Janulíková J, Sebo P, Varečková E., Antiviral Res. 97(1), 24-35, 2013. https://doi. org/10.1016/j.antiviral.2012.09.008

Staneková Z, Király J, Stropkovská A, Mikušková T, Mucha V, Kostolanský F, Varečková E., Acta Virol. 55(1), 61-67, 2011. https://doi.org/10.4149/av_2011_01_61

Staneková Z, Mucha V, Sládková T, Blaškovičová H, Kostolanský F, Varečková E., Influenza Other Respir Viruses 6(6),389-395, 2012. https://doi.org/10.1111/i.17502659.2011.00328.x

Staneková Z, Varečková E., Virol. J. 7, 351, 2010. https://doi. org/10.1186/1743-422X-7-351

Steel J, Lowen AC, Wang TT, Yondola M, Gao Q, Haye K, GarcíaSastre A, Palese P., MBio 1(1), pii: e00018-10, 2010. https://doi.org/10.1128/mBio.00018-10

Steinhauer DA., Virology 258(1), 1-20, 1999. https://doi. org/10.1006/viro.1999.9716

Stepanova LA, Mardanova ES, Shuklina MA, Blokhina EA, Kotlyarov RY, Potapchuk MV, Kovaleva AA, Vidyaeva IG, Korotkov AV, Eletskaya EI, Ravin NV, Tsybalova LM., 
J. Biomed. Sci. 25(1), 33, 2018. https://doi.org/10.1186/ s12929-018-0433-5

Stropkovská A, Janulíková J, Varečková E., Acta Virol. 54(1), 7-19, 2010. https://doi.org/10.4149/av 2010017

Stropkovská A, Mucha V, Fislová T, Gocník M, Kostolanský F, Varečková E., Acta Virol. 53(1), 15-20, 2009. https://doi. org/10.4149/av_2009_01_15

Sui J, Hwang WC, Perez S, Wei G, Aird D, Chen L, Santelli E, Stec B, Cadwell G, Ali M, Wan H, Murakami A, Yammanuru A, Han T, Cox NJ, Bankston LA, Donis RO, Liddington RC, Marasco A., Nat. Struct. Mol. Biol. 16(3), 265-273, 2009. https://doi.org/10.1038/nsmb.1566

Sun W, Zheng A, Miller R, Krammer F, Palese P., Vaccines (Basel) 7(3), 117, 2019. https://doi.org/10.3390/vaccines7030117

Sunwoo SY, Schotsaert M, Morozov I, Davis AS, Li Y, Lee J, McDowell C, Meade P, Nachbagauer R, García-Sastre A, Ma W, Krammer F, Richt JA., Vaccines (Basel) 6(3), 64, 2018. https://doi.org/10.3390/vaccines6030064

Tao W, Ziemer KS, Gill HS., Nanomedicine (Lond). 9(2), 237-251, 2014. https://doi.org/10.2217/nnm.13.58

Tate MD, Job ER, Deng YM, Gunalan V, Maurer-Stroh S, Reading PC., Viruses 6(3), 1294-1316, 2014. https://doi. org/10.3390/v6031294

Tomčíková K, Varečková E., Acta Virol. 63(4), 347-365, 2019. https://doi.org/10.4149/av 2019408

Treanor JJ, Tierney EL, Zabedee SL, Lamb RA, Murphy BR., J. Virol. 64(3), 1375-1377, 1990. https://doi.org/10.1128/ JVI.64.3.1375-1377.1990

Tsybalova LM, Stepanova LA, Shuklina MA, Mardanova ES, Kotlyarov RY, Potapchuk MV, Petrov SA, Blokhina EA, Ravin NV., PLoS One 13(8), e0201429, 2018. https://doi. org/10.1371/journal.pone.0201429

Vaccaro L, Cross KJ, Kleinjung J, Straus SK, Thomas DJ, Wharton SA, Skehel JJ, Fraternali F., Biophys. J. 88(1), 25-36, 2005. https://doi.org/10.1529/biophysj.104.044537

van de Sandt CE, Kreijtz JH, Rimmelzwaan GF., Viruses 4(9), 1438-1476, 2012. https://doi.org/10.3390/v4091438

Varečková E, Mucha V, Kostolanský F., Acta Virol. 57(2), 247-256, 2013. https://doi.org/10.4149/av $201302 \quad 247$

Varečková E, Cox N, Klimov A., J. Clin. Microbiol.40(6),2220-2223, 2002.https://doi.org/10.1128/JCM.40.6.2220-2223.2002

Varečková E, Mucha V, Kostolanský F, Gubareva LV, Klimov A., Virus Res.132(1-2),181-186,2008. https://doi.org/10.1016/j. virusres.2007.10.004
Varečková E, Wharton SA, Mucha V, Gocník M, Kostolanský F., Acta Virol. 47(4), 229-236, 2003b.

Varečková E, Mucha V, Wharton SA, Kostolanský F., Arch Virol. 148(3), 469-486, 2003a. https://doi.org/10.1007/s00705002-0932-1

Vigerust DJ, Ulett KB, Boyd KL, Madsen J, Hawgood S, McCullers JA., J. Virol. 81(16), 8593-8600, 2007. https://doi. org/10.1128/JVI.00769-07

Vogel OA, Manicassamy B., Front Microbiol. 11(135), 14, 2020. https://doi.org/10.3389/fmicb.2020.00135

Wang L, Hess A, Chang TZ, Wang YC, Champion JA, Compans RW, Wang BZ., Nanomedicine 10(2), 473-482, 2014. https:// doi.org/10.1016/j.nano.2013.08.005

Wang TT, Tan GS, Hai R, Pica N, Petersen E, Moran TM, Palese P., PLoS Pathog. 6(2), e1000796, 2010. https://doi. org/10.1371/journal.ppat.1000796

Wharton SA, Belshe RB, Skehel JJ, Hay AJ., J. Gen. Virol. 75 (Pt 4), 945-948, 1994. https://doi.org/10.1099/00221317-75-4-945

Yao Y, Wang H, Chen J, Shao Z, He B, Chen J, Lan J, Chen Q, Chen Z., Emerg. Microbes Infect. 8(1), 45-54,2019. https://doi org/10.1080/22221751.2018.1558962

Yassine HM, Boyington JC, Mctamney PM, Wei CJ, Kanekiyo M, Kong WP, Gallagher JR, Wang L, Zhang Y, Joyce MG, Lingwood D, Moin SM, Andersen H, Okuno Y, Rao SS, Harris AK, Kwong PD, Mascola JR, Nabel GJ, Graham BS., Natur. Med. 21(9), 1065-1070, 2015. https://doi. org/10.1038/nm.3927

Zebedee SL, Lamb RA., J. Virol. 62(8), 2762-2772, 1988. https:// doi.org/10.1128/JVI.62.8.2762-2772.1988

Zebedee SL, Lamb RA., Proc. Natl. Acad. Sci. USA 86(3), 1061-1065, 1989. https://doi.org/10.1073/pnas.86.3.1061

Zhang M, Zharikova D, Mozdzanowska K, Otvos L, Gerhard W., Mol. Immunol. 43(14), 2195-2206, 2006. https://doi. org/10.1016/i.molimm.2005.12.015

Zhang X, Chen S Jiang Y, Huang K, Huang J Yang D, Zhu J, Zhu Y, Shi S, Peng D, Liu X., Vet. Microbiol. 175(2-4), 244-256, 2015. https://doi.org/10.1016/j.vetmic.2014.12.011

Zhong W, Reed C, Blair PJ, Katz JM, Hancock K, Influenza Serology Working Group., J Infect. Dis. 209(7), 986-994, 2014. https://doi.org/10.1093/infdis/jit811 